\title{
Use of plant resources in a seasonal dry forest (Northeastern Brazil)
}

\author{
Ulysses Paulino de Albuquerque ${ }^{1,3}$, Laise de Holanda Cavalcanti Andrade ${ }^{2}$ and Ana Carolina Oliveira de Silva ${ }^{1}$
}

Received: March 10, 2003; Accepted: July 13, 2004

\begin{abstract}
RESUMO - (O uso de recursos vegetais em uma floresta estacional seca (Nordeste do Brasil)). Para estudar o uso de recursos vegetais de uma floresta estacional seca por uma comunidade rural, foram demarcadas parcelas em áreas de vegetação perturbada e relativamente preservada. O estudo foi conduzido em vegetação de caatinga arbórea hiperxerófila situada no município de Alagoinha (08²7' $59^{\prime \prime}$ S e 36 46’33" W), no estado de Pernambuco, Nordeste do Brasil. Os resultados mostram que um padrão semelhante de oferecimento de recursos medicinais foi encontrado ao de outras florestas tropicais, nas quais as áreas perturbadas ou de vegetação secundária são uma maior fonte de plantas medicinais. Todavia, um novo padrão foi evidenciado ao verificar-se que áreas perturbadas não detêm a preferência das pessoas, e que isso pode estar relacionado com a disponibilidade temporal dos recursos (adaptação a estacionalidade característica do tipo vegetacional) e a permanência dos valores culturais e de conhecimentos básicos sobre as plantas da vegetação natural, e que são de maior importância para a comunidade.
\end{abstract}

Palavras-chave: etnobotânica quantitativa, florestas sazonais secas, caatinga, plantas medicinais, diversidade tropical

\begin{abstract}
Use of plant resources in a seasonal dry forest (Northeastern Brazil)). To study the use of plant resources by a rural community in a seasonal dry forest, plots were established in a disturbed area and in a relatively preserved area. The study was carried out in caatinga vegetation located at the municipality of Alagoinha ( $08^{\circ} 27^{\prime} 59^{\prime \prime} \mathrm{S}$ and $\left.36^{\circ} 46^{\prime} 33^{\prime \prime} \mathrm{W}\right)$, state of Pernambuco, Northeastern Brazil. The results show a pattern of medicinal resources offering similar to that found in other tropical forests, in which the disturbed areas or those of secondary vegetation are a major source of medicinal plants. Nevertheless, a new pattern was evidenced as it was found that disturbed areas are not preferred by local people, and that it may be related to temporal availability of resources (adaptation to the characteristic seasonality of the vegetation type) and to the permanence of cultural values and basic knowledge on plants of the natural vegetation, which are of major importance for the community.
\end{abstract}

Key words: quantitative ethnobotany, seasonal dry forests, caatinga, medicinal plants, tropical biodiversity

\section{Introduction}

Researchers devoted to quantitative ethnobotany studies have found a certain preference of people to search out resources, mainly medicinal plants, in disturbed areas as in secondary forests instead of primary forests. Voeks (1996) suggests that the preference for medicinal plants found in disturbed areas reflects cultural changes and loss of traditional botanical knowledge. That study was carried out in the coastal zone of Brazil in an area of Atlantic forest, but Caniago \& Siebert (1998) observed in Indonesia a similar pattern of use of resources. Thus, the study of such patterns on the preference and use of plant resources may contribute to the knowledge of biological and cultural factors that interfere in the traditional botanical knowledge, and may subsidize the management of those resources. Nevertheless, that information leads to a very simple question and yet without a convincing answer: are primary forests a true source of medicinal plants? Several authors affirm it, pointing out that it is a strong utilitarian argument for the conservation of tropical forests (cf. Voeks 1996). Contradictory results suggest that it may vary among different tropical forests. If, in fact, primary forests are a potential source of medicinal resources, it is reasonable to suppose that these forests, or more preserved areas, do concentrate a higher number of medicinal plants than secondary forests and disturbed areas.

This work compares the offering and dynamics of resources in two areas through the plots method. It also was aimed to test the hypothesis of preference for resource source, and to discuss the implications of the data obtained for conservation of the caatinga. The

\footnotetext{
1 Universidade Federal Rural de Pernambuco, Departamento de Biologia, Área de Botânica, Laboratório de Etnobotânica Aplicada, Rua Dom Manoel de Medeiros s/n, Dois Irmãos, CEP 52171-900, Recife, PE, Brazil (www.ufrpe.br/lea)

2 Universidade Federal de Pernambuco, Departamento de Botânica, Laboratório de Etnobotânica e Botânica Aplicada (LEBA), CCB, Cidade Universitária, CEP 50670-901, Recife, PE, Brazil

3 Corresponding Author: upa@ufrpe.br
} 
caatinga vegetation, that covers a large area of Northeastern Brazil, is characterized by water deficiency originated by low rainfall, high potential evapotranspiration and irregular distribution of rainfall (Rodal et al. 1992; Sampaio 1995). According to Sampaio (1995), the flora is little known, including about 339 species of trees and shrubs, being Leguminosae, Euphorbiaceae and Cactaceae the families with higher number of species. The caatinga vegetation does not form a homogeneous structural and floristic complex, but varies according to several factors as soil, xerothermic index, physiognomy and characteristic genera (Sampaio 1995). Along the five last years, at the studied area, the process of degradation and elimination of native covert has been accelerated. Some studies were performed at the region, notably on reproduction and dispersal biology (Griz \& Machado 2001), eco-physiology and ecological anatomy. The area presents similar problems to those found in other localities: lack of systematic studies to subsidize management and conservation programs, and the fact that there are only few protected areas of caatinga (only three in the State of Pernambuco).

\section{Material and methods}

Study area - The study was carried out at the municipality of Alagoinha, sub-zone of the "agreste" of Pernambuco (08'27' 59" S and 36 $46^{\circ} 33^{\prime}$ " W), distant $225.5 \mathrm{Km}$ from Recife (Fidem 2001). The climate is semi-arid of low latitudes, BSHs' according to Köppen's classification. Average annual temperature is of $25^{\circ} \mathrm{C}$ and annual rainfall is of $599 \mathrm{~mm}$, with irregular rainfall distributed along the year. The natural vegetation is a dry tropical forest (caatinga type), which is characterized by the predominance of xerophytic and deciduous species, as well as by species of the families Cactaceae and Bromeliaceae that contribute to formation of the landscape. It presents species that retain their leaves in the dry season, as "juá" (Ziziphus joazeiro Mart.) or are partially deciduous, as "umbu" (Spondias tuberosa Arr. Câm.). The herbaceous stratum is ephemeral, emerging vigorously during the rainy season.

The Cajueiro farm, where the study was carried out, has a vast cover of natural forest, which is suffering strong anthropogenic pressures. Along the years, some places were cut down for expansion of cultured areas or pastures or for providing wood, used for different purposes as timber and fens for delimitation of areas of the farm.
Fieldwork comprised the study of one disturbed area of caatinga and of one area conserved of vegetation. The disturbed area had its native cover cut down about 40 years ago (according to the people of the region). Along the years, it has been used to raise cattle. It is characterized by the herbaceous-sub shrubby stratum and scattered shrubby elements.

Ethnobotanical and Floristic Methods - For obtaining of ethnobotanical information were used two methods: the community survey approach ("artifact/inventory method") and the inventory/interview method (see Mutchnick \& McCarthy 1997). In a second moment, representative samples of the collected plants were shown individually to two main informants, identified during interviews with other 28 local people. All people (26 women and 4 men) normally use and knows local plants for different purposes. These were requested to identify the plants and tell us on their utility. The information obtained was then confronted with other informants and with reports made by the same informants in other opportunities. Those informations on the use of plant resources in the region are presented by Albuquerque \& Andrade (2002a, b).

This study was performed between 1998-1999, during the rainy and dry seasons. Fieldwork aimed to assess the availability and use of plant resources by the community, starting with different sources of supply: anthropogenic disturbed area and forest area with native cover (with systematic sampling design). Aiming to evaluate the availability of useful resources during the dry season, for posterior comparison with the rainy season, an experimental design of 25 quadrants of $2 \times 2 \mathrm{~m}$ each was used in the disturbed area, due the predominance of herbs. All species within the sampling units were collected and identified.

At the area of forest vegetation five plots of $10 \times 20 \mathrm{~m}$ were established, distributed on places under less anthropogenic disturbance, indicated by an informant, considered an experienced "mateiro" among members of the community. The first plot was selected at random. It was assumed that the size of the plots is variable as a function of the nature of the work, objectives of the research and characteristics of the vegetation (Martin 1995) and that application of collector curve is indicative of sampling sufficiency. Thus, it was not employed the area of one hectare widely used in different ethnobotanical researches. To obtain information on identity and importance of the species, the informant was inquired as the samples were collected. That information was complemented with interviews performed with the local inhabitants. In both 
areas studied the collector curve was used, and it indicated the sampling effort to be enough, not withstanding the different size of the areas, therefore being comparable. All species within the sampling units were collected and identified.

The collected species were identified with the aid of analytic keys, by comparison with specimens at the UFP (Departamento de Botânica - CCB - UFPE), and IPA (Dárdano de Andrade-Lima) herbaria and through consultation with specialists. The collections were deposited at the UFP herbarium. In certain situations, the species found in the sampling units were collected in other places, indicated by the informants, because they were in better conditions for the process of herborization and identification. For each species, parameters of density and frequency were calculated based on Rodal et al. (1992).

Data Analyses - $\chi^{2}$ test were used to compare the proportion of plant resources offered by the two studied areas. The technique of Phillips et al. (1994) was employed for calculation of the use-value index and to investigate the general pattern of plant use. Application of the use-value of each species is based objectively on the importance attributed by the informants and does not depend on the opinion of the researcher.

To find potential predictors of importance of the species (use-value) in native vegetation, variables as density and frequency were used in simple regression analyses. Data were log-transformed prior to regression. All statistical analyses were performed using the Systat 5.0 software package.

Data were compared with similar studies, also including tropical rain forests, specially Voeks (1996), just to explicit patterns of use of the tropical resources.

\section{Results and discussion}

Source of useful plants - When the useful species in the two studied areas are compared it is observed that the vegetation typical of caatinga offers a larger amount of resources, being those differences statistically significant $\left(\chi^{2}=6.29, p<0.05\right)$. There are no numerical differences between the amount of medicinal plants offered at the preserved area (15) and the disturbed area (14), but when the proportion of medicinal resources in relation to other use categories is considered as a parameter, it may be said that the disturbed area is a more important source $\left(\chi^{2}=5.88\right.$, $p<0.05)$. According to Sorensen index, the similarity between the two areas is very low $(\mathrm{S}=6.2 \%)$. This was expected, because the disturbed area presents few elements characteristic of caatinga vegetation. With regard to life forms, $100 \%$ of the species found in the disturbed area are herbaceous or shrubs, contrasting with the species found in the preserved area, which are predominantly arboreal or shrubs. Indeed, the preserved area is a larger source of timber products.

Voeks (1996) and Caniago \& Siebert (1998) found a use pattern of medicinal resources similar to that found in the present study, which leads to the inquiry: are, in fact, primary tropical forests are rich source of medicinal resources? Those data suggest that secondary forests and disturbed areas do concentrate a large number of medicinal plants (see also Frei et al. 2000). Voeks (1996) called attention to that fact and concluded that local people prefer to use the medicinal plants of disturbed areas. He attributed that preference to factors as acculturation, high relative availability and to the inherent potential of the species of disturbed areas. In this respect, Voeks (1996) argues that, being the plants of these areas generally herbaceous, they may represent a large source of bioactive compounds.

The data here obtained agree with Voeks, because the disturbed area offers a high relative availability of medicinal resources and, it may be judged, that there was a loss of traditional knowledge, because these areas comprise a large number of weedy species. Nevertheless, it is a misinterpretation for the present case.

The disturbed areas do offer more medicinal plants, but do not withhold the preference of the people. Here it is necessary to make a distinction between the knowledge of a resource and its use. The studied community knows the medicinal plants of the disturbed areas, which mostly are herbaceous plants of short life cycle, but prefers to use the species of the native vegetation, even if it is needed to walk a lot of kilometers to obtain the desirable product. Here a resource preference is characterized. In this study, usepreference of resource is "the conscious choice in using a given resource in detriment of another while simultaneously offered".

Floristic composition and temporal availability - At the disturbed area, during the dry season, 93 individuals distributed in nine species, nine genera and eight families were observed. Whereas during the rainy season, 771 individuals distributed in 30 species, 28 genera and 17 families, besides 1 unknown individual were counted (Tab. 1). During rainy season there was an increase of 22 species, and if the species collected outside the 
Table 1. Species sampled in an disturbed area, municipality of Alagoinha, Pernambuco, Brazil. AD = absolute density (ind/ha); RD = relative density $(\%) ; \mathrm{AF}=$ absolute frequency $(\%) ; \mathrm{RF}=$ relative frequency $(\%) ; \mathrm{N}=$ number of individuals sampled in $100 \mathrm{~m}^{2}$.

\begin{tabular}{|c|c|c|c|c|c|c|c|c|c|c|}
\hline \multirow[t]{2}{*}{ Taxa } & \multicolumn{2}{|c|}{$\mathrm{AD}$} & \multicolumn{2}{|c|}{$\mathrm{RD}$} & \multicolumn{2}{|c|}{$\mathrm{AF}$} & \multicolumn{2}{|c|}{ RF } & \multicolumn{2}{|c|}{$\mathrm{N}$} \\
\hline & rainy & dry & rainy & dry & rainy & dry & rainy & dry & rainy & dry \\
\hline \multicolumn{11}{|l|}{ AMARANTHACEAE } \\
\hline Amaranthus spinosus L. & 500 & - & 0.64 & - & 8 & - & 1.18 & - & 5 & - \\
\hline Alternanthera tenella Colla. & 500 & - & 0.64 & - & 8 & - & 1.18 & - & 5 & - \\
\hline \multicolumn{11}{|l|}{ ASTERACEAE } \\
\hline Egletes viscosa Less. & 300 & 100 & 0.38 & 1.07 & 4 & 4 & 0.59 & 2.56 & 3 & 1 \\
\hline Eclipta prostrata (L.) L. & 1,700 & - & 2.20 & - & 16 & - & 2.36 & - & 17 & - \\
\hline Tridax procumbens L. & 100 & - & 0.12 & - & 4 & - & 0.59 & - & 1 & - \\
\hline \multicolumn{11}{|l|}{ CAESALPINIACEAE } \\
\hline $\begin{array}{l}\text { Chamaecrista rotundifolia (Pers.) Greene } \\
\text { var. rotundifolia }\end{array}$ & 100 & - & 0.12 & - & 4 & - & 0.59 & - & 1 & - \\
\hline $\begin{array}{l}\text { Senna martiana (Benth.) H.S. Irwin \& } \\
\text { Barneby }\end{array}$ & 700 & 1,000 & 0.90 & 10.75 & 20 & 12 & 2.95 & 7.69 & 7 & 10 \\
\hline Senna obtusifolia (L.) H.S. Irwin \& Barneby & 300 & - & 0.38 & - & 4 & - & 0.59 & - & 3 & - \\
\hline \multicolumn{11}{|l|}{ CAPPARACEAE } \\
\hline Cleome spinosa Jacq. & 15,500 & 5,300 & 20.10 & 56.98 & 92 & 72 & 13.60 & 46.15 & 155 & 53 \\
\hline \multicolumn{11}{|l|}{ CONVOLVULACEAE } \\
\hline Evolvulus filipes Mart. & 1,600 & - & 2.07 & - & 24 & - & 3.55 & - & 16 & - \\
\hline \multicolumn{11}{|l|}{ CUCURBITACEAE } \\
\hline Luffa sp. & 100 & - & 0.12 & - & 4 & - & 0.59 & - & 1 & - \\
\hline \multicolumn{11}{|l|}{ EUPHORBIACEAE } \\
\hline Cnidoscolus urens (L.) Arthur & 200 & 400 & 0.25 & 4.30 & 4 & 12 & 0.59 & 7.69 & 2 & 4 \\
\hline Croton rhamnifolius (Kunth.) Muell. & 500 & 600 & 0.64 & 6.45 & 20 & 16 & 2.95 & 10.25 & 5 & 6 \\
\hline Chamaesyce hyssopifolia (L.) Small. & 900 & - & 1.16 & - & 16 & - & 2.36 & - & 9 & - \\
\hline Euphorbia prostrata Ait. & 500 & - & 0.64 & - & 12 & - & 1.77 & - & 5 & - \\
\hline \multicolumn{11}{|l|}{ FABACEAE } \\
\hline Desmodium procumbens (Mill.) Hich. & 100 & - & 0.12 & - & 4 & - & 0.59 & - & 1 & - \\
\hline \multicolumn{11}{|l|}{ MALVACEAE } \\
\hline Gaya dominguensis Ulbr. & 200 & - & 0.25 & - & 4 & - & 0.59 & - & 2 & - \\
\hline Herissantia tiubae (K. Sch.) Briz. & 3,800 & 100 & 4.92 & 1.07 & 40 & 4 & 5.91 & 2.56 & 38 & 1 \\
\hline Sidastrum paniculatum (L.) Fryxell. & 5,600 & - & 7.26 & - & 48 & - & 7.10 & - & 56 & - \\
\hline \multicolumn{11}{|l|}{ MOLUGINACEAE } \\
\hline Mollugo verticillata $\mathrm{L}$. & 17,900 & - & 23.21 & - & 72 & - & 10.65 & - & 179 & - \\
\hline Glinus radiatus (Ruiz \& Pavón) Rohrbach. & 4,800 & - & 6.22 & - & 16 & - & 2.36 & - & 48 & - \\
\hline \multicolumn{11}{|l|}{ NYCTAGINACEAE } \\
\hline Boerhavia diffusa L. & 400 & - & 0.51 & - & 16 & - & 2.36 & - & 4 & - \\
\hline \multicolumn{11}{|l|}{ PAPAVERACEAE } \\
\hline Argemone mexicana L. & 1,700 & 100 & 2.20 & 1.07 & 32 & 4 & 4.73 & 2.56 & 17 & 1 \\
\hline \multicolumn{11}{|l|}{ POACEAE } \\
\hline Echinocloa colonum (L.) Link. & 300 & - & 0.38 & - & 12 & - & 1.77 & - & 3 & - \\
\hline Panicum trichoides Swartz & 2,700 & - & 3.50 & - & 28 & - & 4.14 & - & 27 & - \\
\hline PORTULACACEAE & & & & & & & & & & \\
\hline Portulaca oleracea L. & 7,800 & - & 10.11 & - & 60 & - & 8.87 & - & 78 & - \\
\hline Portulaca pilosa $\mathrm{L}$. & 100 & - & 0.12 & - & 4 & - & 0.59 & - & 1 & - \\
\hline SAPINDACEAE & & & & & & & & & & \\
\hline Serjania comata Radlk. & 100 & 200 & 0.12 & 1.15 & 4 & 4 & 0.59 & 2.56 & 1 & 2 \\
\hline SOLANACEAE & & & & & & & & & & \\
\hline Solanum paniculatum L. & 1,600 & 1,500 & 2.07 & 16.12 & 20 & 28 & 2.95 & 17.94 & 16 & 15 \\
\hline STERCULIACEAE & & & & & & & & & & \\
\hline Melochia tomentosa $\mathrm{L}$. & 6,400 & - & 8.30 & - & 72 & - & 10.65 & - & 64 & - \\
\hline UNIDENTIFIEDS & 100 & - & 0.12 & - & 4 & - & 0.59 & - & 1 & - \\
\hline
\end{tabular}


plots were considered, this number rises up to 39 species (Tab. 3). The 30 species sampled in the floristic survey are presented in tab. 1, together with their respective values of density and frequency. The families with higher number of species were: Euphorbiaceae (4 spp.) and Caesalpiniaceae (5 spp.), followed by Malvaceae, Asteraceae and Poaceae, each with three species. The other families contributed with one or two species. Among genera, the most notable were Senna and Portulaca, with two species both. The highest density $(56.98 \%)$ and relative frequency $(46.15 \%)$ during dry season was recorded for Cleome spinosa, followed by Solanum paniculatum (16.12\%, $17.94 \%)$ and Senna martiana (10.75\%, 7.69\%). Together, these three species totalize $83.87 \%$ of the individuals sampled at the area. The other species had values between $6.45 \%$ and $1.07 \%$. During rainy season, the highest densities were recorded for Mollugo verticillata $(23,21 \%)$, followed by Cleome spinosa (20.10\%) and Portulaca oleracea (10.11\%). Among the other species, 10 had values between $8.3 \%$ and $1.16 \%$ and 17 appear with values inferior to $1 \%$ of relative density. At the start of the rainy season, $M$. verticillata presented a higher relative density.

Though there is a certain abundance of resources, and though the interviewed persons consider $48.38 \%$ of the resources useful, local community seems to ignore them; of these $53.33 \%$ are available in the dry season and correspond to eight species (Tab. 1 and 3). The informants indicated $45.16 \%$ of the species for medicinal purposes, and only Amaranthus spinosus was indicated as edible. Nevertheless, though that expressive percentage of useful plants, the local community recognizes their utility but uses them in a low frequency, preferring the arboreal species of the native vegetation. In many instances the informants knew the use of the plant, but clearly indicated that it was used only in the absence of others. The same behavior was observed in relation to the plants collected at the preserved forest, but that were available only during the short rainy season, suggesting that the preference for a resource may be related to its offering period. Floristic and ecological data are very important when trying to understand the dynamics of plant resources-people relationships. It is reasonable to suppose that, as a function of the ephemeral characteristic of the herbaceous stratum of the caatinga, people have developed more profound relationships with the shrubby and arboreal components of the vegetation, which are present for longer periods, and have adapted to the demand of offered products in specific periods. Important biological and sociocultural factors permeate the relationships of people with the caatinga ecosystem. Conservationists and developers should consider such factors in their planning and programs.

At the preserved forest, at the start of the rainy season, 373 individuals, distributed in 17 families, 25 genera and 34 species were counted, besides two unknown individuals (Tab. 2). The most notable families in number of species were: Cactaceae (6 spp.), Mimosaceae (6 spp.), Euphorbiaceae (4 spp.) and Caesalpiniaceae (3 spp.). The other families contributed with one or two species. Among genera, the most notable was Croton, with three species, followed by Caesalpinia, Cordia, Opuntia, Pilosocereus and Piptadenia, all with two species, characteristic of the vegetation type. The higher relative density and frequency were recorded for Croton argirophylloides $(28.68 \%, 6.49 \%)$, followed by Caesalpinia pyramidalis $(15.28 \%, 6.49 \%)$ and Croton sonderianus $(9.91 \%, 1.29 \%)$. Together, these three species comprise $53.88 \%$ of the total of individuals at the sampling area (Tab. 2). Anadenanthera colubrina var. cebil and Melochia tomentosa are also frequent, with $5.19 \%$ of relative frequency. The other species have values of relative frequency between $3.89 \%$ and $1.29 \%$. Almost all of the sampled species are available to the community during the dry season, because the physiognomy is determined by shrubby-arboreal elements that provide their trunk or branches as products to the community.

More than half of the species recorded at the preserved forest $(81.08 \%)$ have known local uses (Tab. 3). Among the uses cited, are: structural timber and firewood, traditional medicine and edible species. Among the listed species with higher relative densities and frequencies, most $(83.33 \%)$ are used as medicine and/or have their wood used in the manner mentioned above. Among them, Croton argirophylloides, Caesalpinia pyramidalis, Croton rhamnifolius, Anadenanthera colubrina var. cebil and Melochia tomentosa are outstanding. Of the registered species, $35.13 \%$ are used exclusively for obtainment of wood and only $13.51 \%$ for medicinal purposes.

The relation between floristic composition and temporal availability of resources is important for the understanding of the dynamics of resource use. Sharma \& Sharma (1997) carried out a similar approach to that of the present study in a semi-arid region of Pushkar (Rajasthan, India), investigating the use and availability of medicinal plants during three seasons. 
Table 2. Species sampled in caatinga vegetation, municipality of Alagoinha, Pernambuco, Brazil. AD = absolute density (ind/ha); $\mathrm{RD}=$ relative density $(\%) ; \mathrm{AF}=$ absolute frequency $(\%) ; \mathrm{RF}=$ relative frequency $(\%) ; \mathrm{N}=$ number of individuals sampled in 0.1 ha.

\begin{tabular}{|c|c|c|c|c|c|}
\hline Taxa & $\mathrm{AD}$ & $\mathrm{RD}$ & $\mathrm{AF}$ & $\mathrm{RF}$ & $\mathrm{N}$ \\
\hline \multicolumn{6}{|l|}{ AMARANTHACEAE } \\
\hline Gomphrena vaga Mart. & 60 & 1.60 & 60 & 3.89 & 6 \\
\hline \multicolumn{6}{|l|}{ ANACARDIACEAE } \\
\hline Myracrodruon urundeuva (Engl.) Fr. All. & 10 & 0.26 & 20 & 1.29 & 1 \\
\hline Schinopsis brasiliensis Engl. & 60 & 1.60 & 40 & 2.59 & 6 \\
\hline \multicolumn{6}{|l|}{ APOCYNACEAE } \\
\hline Aspidosperma pyrifolium Mart. & 10 & 0.26 & 20 & 1.29 & 1 \\
\hline \multicolumn{6}{|l|}{ BORAGINACEAE } \\
\hline Cordia leucocephala Moric & 100 & 2.68 & 60 & 3.89 & 10 \\
\hline C. globosa (Jacq.) H.B.K. & 70 & 1.87 & 40 & 2.59 & 7 \\
\hline \multicolumn{6}{|l|}{ CACTACEAE } \\
\hline Cereus jamacaru DC. & 20 & 0.53 & 40 & 2.59 & 2 \\
\hline Harrisia adscendens (Guercke) Britton \& Rose & 10 & 0.26 & 20 & 1.29 & 1 \\
\hline Opuntia inamoena K. Schumann & 10 & 0.26 & 20 & 1.29 & 1 \\
\hline O. palmadora Britton \& Rose & 40 & 1.07 & 40 & 2.59 & 4 \\
\hline Pilosocereus gounellei (Weber) Byles \& Rowley subsp. gounellei & 30 & 0.80 & 40 & 2.59 & 3 \\
\hline P. pachycladus Ritter subsp. pernambucoensis (Ritter) Zappi & 110 & 2.94 & 60 & 3.89 & 11 \\
\hline \multicolumn{6}{|l|}{ CAESALPINIACEAE } \\
\hline Bauhinia cheilantha (Bong.) Steud. & 20 & 0.53 & 20 & 1.29 & 2 \\
\hline Caesalpinia ferrea Mart. & 10 & 0.26 & 20 & 1.29 & 1 \\
\hline C. pyramidalis Tul. & 570 & 15.28 & 100 & 6.49 & 57 \\
\hline \multicolumn{6}{|l|}{ CELASTRACEAE } \\
\hline Maytenus rigida Mart. & 20 & 0.53 & 20 & 1.29 & 2 \\
\hline \multicolumn{6}{|l|}{ COMBRETACEAE } \\
\hline Thiloa glaucocarpa (Mart.) Eichl. & 40 & 1.07 & 60 & 3.89 & 4 \\
\hline \multicolumn{6}{|l|}{ EUPHORBIACEAE } \\
\hline Croton argirophylloides Muell Arg. & 1,070 & 28.68 & 100 & 6.49 & 107 \\
\hline C. sonderianus Muell. Arg. & 370 & 9.91 & 20 & 1.29 & 37 \\
\hline C. rhamnifolius Muell. Arg. & 250 & 6.70 & 100 & 6.49 & 25 \\
\hline Jatropha mollissima (Pohl.) Baill. & 30 & 0.80 & 40 & 2.59 & 3 \\
\hline \multicolumn{6}{|l|}{ MIMOSACEAE } \\
\hline Anadenanthera colubrina (Vell.) Brenan var. cebil (Griseb.) Altschul & 140 & 3.75 & 80 & 5.19 & 14 \\
\hline Piptadenia stipulacea Ducke & 10 & 0.26 & 20 & 1.29 & 1 \\
\hline P. zehntneri Harms. & 10 & 0.26 & 20 & 1.29 & 1 \\
\hline Mimosa cf. malacocentra Mart. & 10 & 0.26 & 20 & 1.29 & 1 \\
\hline M. tenuiflora (Willd.) Poir. & 10 & 0.26 & 20 & 1.29 & 1 \\
\hline M. arenosa (Willd.) Poir. & 60 & 1.60 & 40 & 2.59 & 6 \\
\hline \multicolumn{6}{|l|}{ POLYGONACEAE } \\
\hline Ruprechtia sp. & 10 & 0.26 & 20 & 1.29 & 1 \\
\hline \multicolumn{6}{|l|}{ RHAMNACEAE } \\
\hline Ziziphus joazeiro Mart. & 10 & 0.26 & 20 & 1.29 & 1 \\
\hline \multicolumn{6}{|l|}{ SAPINDACEAE } \\
\hline Cardiospermum halicacabum $\mathrm{L}$. & 10 & 0.26 & 20 & 1.29 & 1 \\
\hline \multicolumn{6}{|l|}{ SOLANACEAE } \\
\hline Capsicum parvifolium Sendt. & 90 & 2.40 & 80 & 5.18 & 9 \\
\hline \multicolumn{6}{|l|}{ STERCULIACEAE } \\
\hline Melochia tomentosa $\mathrm{L}$. & 260 & 6.97 & 80 & 5.19 & 26 \\
\hline \multicolumn{6}{|l|}{ VERBENACEAE } \\
\hline Lantana cf. catinguensis Moldr. & 50 & 1.34 & 60 & 3.89 & 5 \\
\hline \multicolumn{6}{|l|}{ OXALIDACEAE } \\
\hline Oxalis insipida A.St.-Hil. & 130 & 3.48 & 80 & 5.19 & 13 \\
\hline UNIDENTIFIELD 1 & 10 & 0.26 & 20 & 1.29 & 1 \\
\hline UNIDENTIFIELD 2 & 10 & 0.26 & 20 & 1.29 & 1 \\
\hline
\end{tabular}


Table 3. Species inventoried in one disturbed area and one typical of caatinga vegetation at the municipality of Alagoinha, Pernambuco, Brazil, with respective use-value for those considered useful. Species marked with an asterisk were collected outside the sampling units and are included only as a record of the diversity. $\mathrm{DI}=$ disturbed; $\mathrm{PR}=$ preserved vegetation; $\mathrm{A}=$ edible; $\mathrm{B}=$ medicinal; $\mathrm{C}=$ wood; $\mathrm{D}=$ domestic use

\begin{tabular}{|c|c|c|c|c|c|}
\hline Taxa & Vernacular name & Voucher & Uses & Use-value & Area \\
\hline \multicolumn{6}{|l|}{ AMARANTHACEAE } \\
\hline Amaranthus spinosus L. & bredo-de-espinho & 24312 & A & 0.750 & DI \\
\hline Alternanthera tenella Colla. & - & 24243 & - & - & DI \\
\hline Gomphrena vaga Mart. & alento & 24762 & $\mathrm{~B}$ & 0.750 & DI \\
\hline \multicolumn{6}{|l|}{ ANACARDIACEAE } \\
\hline Myracrodruon urundeuva (Engl.) Fr. All. & aroeira & 24769 & $\mathrm{~B}, \mathrm{C}$ & 1.500 & PR \\
\hline Schinopsis brasiliensis Engl.) & baraúna & 23746 & $\mathrm{~B}, \mathrm{C}$ & 1.500 & PR \\
\hline \multicolumn{6}{|l|}{ APOCYNACEAE } \\
\hline Aspidosperma pyrifolium Mart. & pereiro & 24318 & $\mathrm{C}$ & 1.000 & PR \\
\hline \multicolumn{6}{|l|}{ ASTERACEAE } \\
\hline Acmella uliginosa (Sw.) Cass. & - & 24792 & - & - & DI \\
\hline Ageratum conyzoides L.* & - & 24833 & $\mathrm{~B}$ & 0.500 & DI \\
\hline Bidens pilosa L.* & - & 24791 & - & - & DI \\
\hline Chrysantellum americanum (L.) Vatke* & - & 24790 & - & - & DI \\
\hline Centratherum punctatum Cass.* & - & 24794 & - & - & DI \\
\hline Delilia biflora (L.) Kunth.* & - & 24789 & - & - & DI \\
\hline Egletes viscosa Less. & - & 23450 & $\mathrm{~B}$ & 0.500 & DI \\
\hline Eclipta prostrata (L.) L. & - & 24301 & - & - & DI \\
\hline Tridax procumbens $\mathrm{L}$. & - & 24776 & - & - & DI \\
\hline \multicolumn{6}{|l|}{ BORAGINACEAE } \\
\hline Cordia leucocephala Moric & moleque-duro & 24827 & $\mathrm{~A}, \mathrm{C}$ & 1.500 & PR \\
\hline C. globosa (Jacq.) H.B.K. & - & 24784 & $\mathrm{C}$ & 0.500 & PR \\
\hline Heliotropium indicum L.* & fedegoso & 24829 & $\mathrm{~B}$ & 0.500 & DI \\
\hline \multicolumn{6}{|l|}{ CACTACEAE } \\
\hline Cereus jamacaru DC. & mandacaru & $?$ & $\mathrm{~B}$ & 0.500 & PR \\
\hline Harrisia adscendens (Guercke) Britton \& Rose & rabo-de-raposa & 24755 & - & - & PR \\
\hline Opuntia inamoena $\mathrm{K}$. Schumann & palminha & 24751 & - & - & PR \\
\hline O. palmadora Britton \& Rose & quipá & 24754 & - & - & PR \\
\hline Pilosocereus gounellei (Weber) Byles \& Rowley subsp. gounellei & alastrado & 24753 & - & - & PR \\
\hline P. pachycladus Ritter subsp. pernambucoensis (Ritter) Zappi & facheiro & 24752 & - & - & PR \\
\hline \multicolumn{6}{|l|}{ CAESALPINIACEAE } \\
\hline Bauhinia cheilantha (Bong.) Steud. & mororó & 24767 & $\mathrm{~A}, \mathrm{~B}, \mathrm{C}$ & 1.500 & PR \\
\hline Caesalpinia ferrea Mart. & jucá & 23635 & $\mathrm{~B}, \mathrm{C}$ & 1.000 & PR \\
\hline C. pyramidalis Tul. & catingueira & 23680 & $\mathrm{~B}, \mathrm{C}$ & 1.250 & $\mathrm{PR}$ \\
\hline Chamaecrista rotundifolia (Pers.) Greene var. rotundifolia & estralador & 24320 & - & - & DI \\
\hline Senna martiana (Benth.) H.S. Irwin \& Barneby & canafístula & 23444 & $\mathrm{~B}$ & 0.500 & DI \\
\hline S. obtusifolia (L.) H.S. Irwin \& Barneby & matapasto & 24319 & - & - & DI \\
\hline \multicolumn{6}{|l|}{ CAPPARACEAE } \\
\hline Cleome spinosa Jacq. & mussambê & 23448 & $\mathrm{~B}$ & 0.833 & DI \\
\hline \multicolumn{6}{|l|}{ CELASTRACEAE } \\
\hline Maytenus rigida Mart. & bom-nome & 23383 & $\mathrm{~B}, \mathrm{C}$ & 1.250 & PR \\
\hline \multicolumn{6}{|l|}{ CHENOPODIACEAE } \\
\hline Chenopodium sp.* & - & 24783 & - & - & DI \\
\hline \multicolumn{6}{|l|}{ COMBRETACEAE } \\
\hline Thiloa glaucocarpa (Mart.) Eichl. & supaúba & 24839 & $\mathrm{C}$ & 1.000 & PR \\
\hline \multicolumn{6}{|l|}{ CONVOLVULACEAE } \\
\hline Evolvulus filipes Mart. & - & 24827 & - & - & DI \\
\hline Ipomoea acuminata $\mathrm{R}$. et Sch.* & - & 24826 & - & - & DI \\
\hline \multicolumn{6}{|l|}{ CUCURBITACEAE } \\
\hline Luffa sp. & - & 24825 & - & - & DI \\
\hline \multicolumn{6}{|l|}{ EUPHORBIACEAE } \\
\hline Cnidoscolus urens (L.) Arthur & urtiga & 23442 & $\mathrm{~B}$ & 1.000 & DI \\
\hline Croton argirophylloides Muell Arg. & sacatinga & 24314 & $\mathrm{~B}, \mathrm{C}, \mathrm{D}$ & 1.125 & PR \\
\hline C. sonderianus Muell. Arg. & marmeleiro & 24768 & $\mathrm{~B}, \mathrm{C}$ & 1.000 & PR \\
\hline C. rhamnifolius (Kunth.) Muell. Arg. & velame & 24238 & $\mathrm{~B}$ & 0.833 & PR,DI \\
\hline
\end{tabular}


Table 2 (continuation)

\begin{tabular}{|c|c|c|c|c|c|}
\hline Taxa & Vernacular name & Voucher & Uses & Use-value & Area \\
\hline \multicolumn{6}{|l|}{ EUPHORBIACEAE } \\
\hline Chamaesyce hyssopifolia (L.) Small. & quebra-pedra & 24246 & $\mathrm{~B}$ & 0.500 & DI \\
\hline Euphorbia geniculata Ort.* & - & 24831 & - & - & DI \\
\hline E. prostrata Ait. & quebra-pedra & 24308 & B & 0.500 & DI \\
\hline Jatropha mollissima (Pohl.) Baill. & pinhão-branco & 23377 & $\mathrm{~B}$ & 1.000 & PR \\
\hline \multicolumn{6}{|l|}{ FABACEAE } \\
\hline Desmodium glabrum (Mill.) DC.* & engorda-cavalo & 24834 & - & - & DI \\
\hline D. procumbens (Mill.) Hich. & - & 24830 & - & - & DI \\
\hline \multicolumn{6}{|l|}{ LAMIACEAE } \\
\hline Marsypianthes chamaedrys (Vahl) Kuntze* & meladinha & 24467 & - & - & DI \\
\hline Ocimum campechianum Mill.* & mangericão & 24761 & $\mathrm{~B}$ & 0.500 & DI \\
\hline \multicolumn{6}{|l|}{ MALVACEAE } \\
\hline Gaya dominguensis Ulbr. & - & 24277 & - & - & DI \\
\hline Herissantia tiubae (K. Sch.) Briz. & mela-bode & 24728 & - & - & DI \\
\hline Sidastrum paniculatum (L.) Fryxell & - & 24675 & - & - & DI \\
\hline \multicolumn{6}{|l|}{ MIMOSACEAE } \\
\hline Anadenanthera colubrina (Vell.) Brenan var. cebil (Griseb.) Altschul & angico & 23634 & $\mathrm{~B}, \mathrm{C}$ & 1.500 & PR \\
\hline Piptadenia stipulacea Ducke & carcará & 23717 & $\mathrm{C}$ & 1.000 & PR \\
\hline P. zehntneri Harms. & angico-liso & 24249 & $\mathrm{C}$ & 1.000 & PR \\
\hline Mimosa cf. malacocentra Mart. & rasga-beiço & 24766 & $\mathrm{C}$ & 1.000 & PR \\
\hline M. tenuiflora (Willd.) Poir. & jurema & 24835 & $\mathrm{C}$ & 1.000 & PR \\
\hline M. arenosa (Willd.) Poir. & avoador & 24836 & $\mathrm{C}$ & 1.000 & PR \\
\hline \multicolumn{6}{|l|}{ MOLUGINACEAE } \\
\hline Mollugo verticillata $\mathrm{L}$. & - & 24307 & - & - & DI \\
\hline Glinus radiatus (Ruiz \& Pavón) Rohrbach. & - & 24286 & - & - & DI \\
\hline \multicolumn{6}{|l|}{ NYCTAGINACEAE } \\
\hline Boerhavia diffusa $\mathrm{L}$. & pega-pinto & 24236 & $\mathrm{~B}$ & 0.750 & DI \\
\hline \multicolumn{6}{|l|}{ OXALIDACEAE } \\
\hline Oxalis insipida A. St.-Hil. & chumbinho & 24838 & A & 1.000 & PR \\
\hline \multicolumn{6}{|l|}{ PAPAVERACEAE } \\
\hline Argemone mexicana $\mathrm{L}$. & cardo-santo & 24237 & $\mathrm{~B}$ & 1.000 & DI \\
\hline \multicolumn{6}{|l|}{ POACEAE } \\
\hline Echinocloa colonum (L.) Link. & unha-de-gato & 24290 & $\mathrm{~B}$ & 0.750 & DI \\
\hline Eragrostis ciliaris (L.) Link* & - & 24788 & - & - & DI \\
\hline Panicum trichoides Swartz & - & 24785 & - & - & DI \\
\hline Tragus berteronianus Schult.* & - & 24826 & - & - & DI \\
\hline \multicolumn{6}{|l|}{ POLYGONACEAE } \\
\hline Ruprechtia sp. & caixão & 24770 & $\mathrm{C}$ & 1.000 & PR \\
\hline \multicolumn{6}{|l|}{ PORTULACACEAE } \\
\hline Portulaca oleracea $\mathrm{L}$. & beldroega & 24774 & B & 0.500 & DI \\
\hline P. pilosa $\mathrm{L}$. & & 24282 & & & DI \\
\hline \multicolumn{6}{|l|}{ RHAMNACEAE } \\
\hline Ziziphus joazeiro Mart. & juá & 23644 & $\mathrm{~A}, \mathrm{~B}$ & 1.000 & PR \\
\hline \multicolumn{6}{|l|}{ RUBIACEAE } \\
\hline Richardia grandiflora (Cham. \& Schl.) Schult. \& Schult.* & - & 24796 & - & - & DI \\
\hline \multicolumn{6}{|l|}{ SAPINDACEAE } \\
\hline Cardiosperrmum halicacabum $\mathrm{L}$. & rama & 24828 & - & - & PR \\
\hline Serjania comata Radlk. & ariu & 23443 & $\mathrm{~B}$ & 0.750 & DI \\
\hline \multicolumn{6}{|l|}{ SOLANACEAE } \\
\hline Capsicum parrvifolium Sendt. & imenta-de-passarinho & 24782 & $\mathrm{C}$ & 1.000 & PR \\
\hline Solanum paniculatum $\mathrm{L}$. & jurubeba & 24449 & $\mathrm{~B}$ & 1.000 & DI \\
\hline STERCULIACEAE & & & & & \\
\hline Melochia tomentosa $\mathrm{L}$. & vermelhinho, malva & 24280 & $\mathrm{~B}$ & 1.000 & PR,DI \\
\hline TILIACEAE & & & & & \\
\hline Corchorus hirtus L.* & - & 24837 & - & - & DI \\
\hline VERBENACEAE & & & & & \\
\hline Lantana cf. catinguensis Moldr. & camará & 24765 & - & - & PR \\
\hline UNIDENTIFIED 1 & pau-vidro & 24966 & $\mathrm{C}$ & 1.000 & PR \\
\hline UNIDENTIFIED 2 & cabeça-de-negro & 24960 & $\mathrm{C}$ & 1.000 & PR \\
\hline UNIDENTIFIED 3 & - & - & - & - & DI \\
\hline
\end{tabular}


Unlike this work, they observed that floristic composition was very similar in the three seasons, having species that occurred in all seasons. Of the 58 species recorded, the community considered $32.75 \%$ useful. Of these, $73.6 \%$ were of medicinal use. Those data are very similar to the data found in the disturbed caatinga, with respect to species use, but differ in the floristic dynamics, even when considering the semiarid factor as a point of convergence. The common feature in both studies is the fact that the species most important for the community are not necessarily the most abundant or important from the ecological point of view, with few exceptions (see also Mutchnick \& McCarthy 1997).

Though the diversity of the preserved area seems low, for only 34 species were recorded in the present survey, this number is in accordance with the diversity of species recorded for other areas of caatinga in Pernambuco (Araújo et al. 1995; Alcoforado Filho et al. 2003; Nascimento et al. 2003). Comparing the obtained floristic list with that of Griz \& Machado (2001), which quotes 41 species in 1.0 ha of native vegetation, at the same place of the present study, 19 species are common to both studies. The other 22 species were not observed in the region or occur as scattered individuals. They are: Acacia bahiensis, Commifera leptophloeos, Capparis flexuosa, Cissus coccinea, C. erosa, Cnidoscolus bahianus, Combretum pisonioides, Croton pohlianus, Dioclea grandiflora, Erythrina velutina, Eugenia sp., Helicteres mollis, Ipomea aff. sericophylla, Jacquemontia cf. hirsuta, Janusia schwanioides, Jatropha ribifolia var. ribifolia, Lantana camara, Malvastrum aff. scoparium, Manihot glaziovii, Melocactus bahiensis, Serjania comata and Spondias tuberosa. Some factors may be used to justify the results of this study in relation to that of Griz \& Machado (2001). Sampling sufficiency may be a convincing hypothesis, because the sampling area used in this study was of 0.1 ha, that is, 10 times smaller than that surveyed by Griz \& Machado (2001). Nevertheless, the collector curve revealed that the number of plots utilized was sufficient. Another possibility may be related to the low frequency and density in which the species occur. Even so, looking at the present conservation status of the area, it seems more reasonable to infer that along the last four years there occurred a expressive but not significant loss of diversity (Test- $G=0.228, p>0.05$ ).

Use-Value of resources and ecological transparency The most important families were: Anacardiaceae
(1.500), Mimosaceae (1.083), Caesalpiniaceae (1.062), Euphorbiaceae (0.851) and Boraginaceae (0.833). Those families have tree species of important ecological and economic role in the caatinga, some of them are considered important edible resources, as Spondias tuberosa Arr. Cam. Still within the Anacardiaceae, Myracrodruon urundeuva and Schinopsis brasiliensis are very important species and have the peculiarity of being wide distributed along seasonal dry forests of South America.

Density and frequency, according to regression analyses, were not significant variables to explain the importance of the species (Fig. 1), respectively: $\mathrm{F}=0.070, \mathrm{p}=0.789, \mathrm{R}^{2}=0,26 \% ; \mathrm{F}=0.004, \mathrm{p}=0.948$, $\mathrm{R}^{2}=0.02 \%$. All the species surveyed and the respective use-value for those considered useful locally is presented in Tab. 3. To indicate these species it was taken as criterion those that presented a use-value superior or equal than one, as: Myracrodruon urundeuva, Schinopsis brasiliensis, Bauhinia cheilantha, Caesalpinia pyramidalis, Croton argirophylloides and Anadenanthera colubrina var. cebil. Those species are an important source of medicinal products, of which medicaments are produced for diabetes, inflammatory and for digestive disturbances. All provide bark and the leaves are rarely used. Future availability of medicinal plants in preserved areas may be seriously threatened by destructive harvesting procedures practiced in the region, not so much by the pressure exerted by the local community, but by the commercial interest associated to some medicinal species that are used for the manufacture of industrialized products, as, for instance, Myracrodruon urundeuva (aroeira) and Anadenanthera colubrina var. cebil (angico). In terms of conservation, those species and others, which utilized parts are the inner bark for medicinal purposes or the total bark for timber, even the abundant with intense use, should deserve attention in future studies on specific techniques of management aiming to sustainable productivity and yield.

Comparing this study with that of Almeida et al. (1995) on the use of resources at the Reserva Extrativista do Cajari (Amapá, Brazil), it is observed that the authors found convergence between abundant species and those of main extractive interest. However, the same does not occur in the studied area, because the most used species have low frequency and density, among these, Myracrodruon urundeuva, Aspidosperma pyrifolium, Bauhinia cheilantha, Caesalpinia ferrea, Maytenus rigida, Piptadenia 


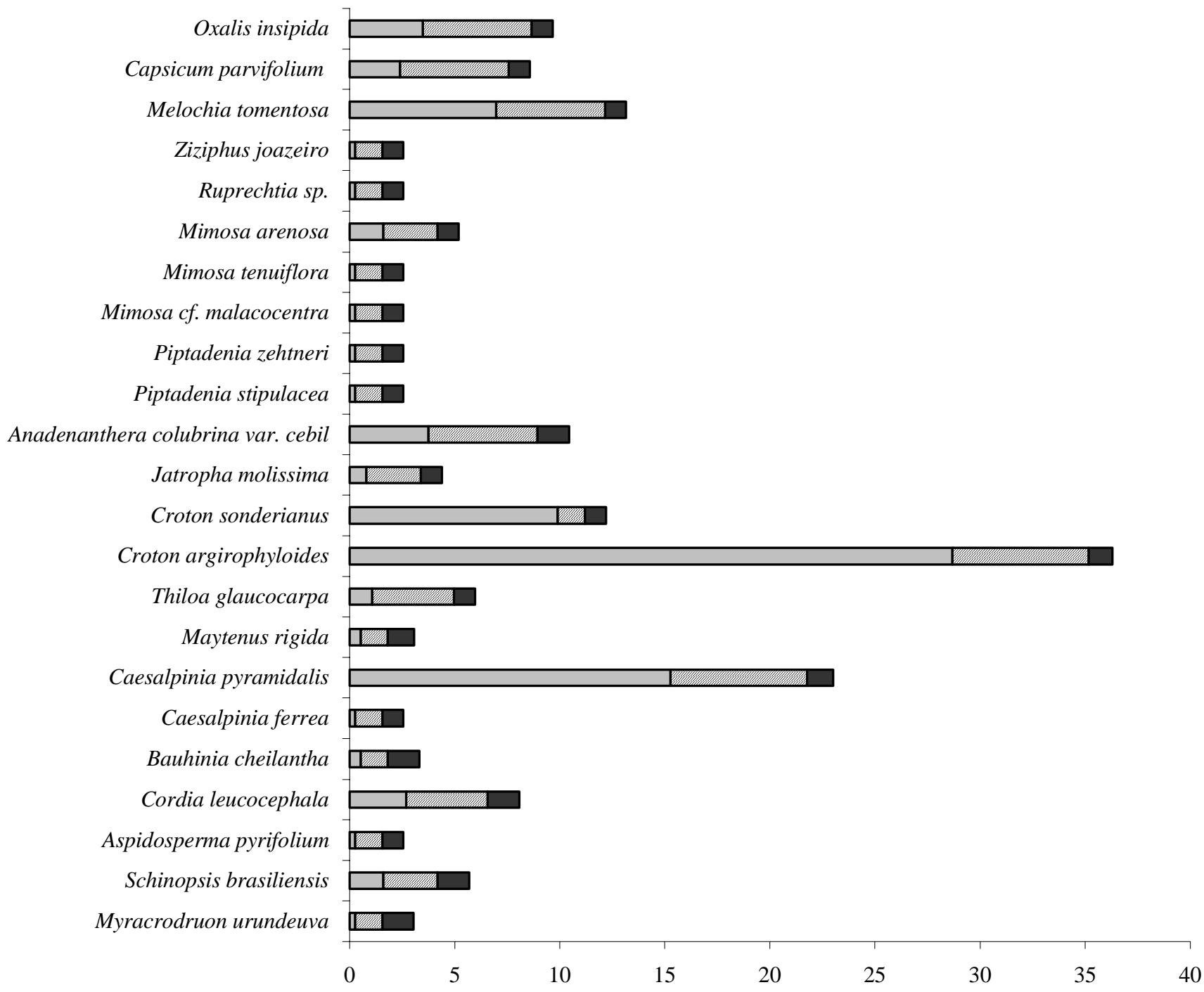

Figure 1. Distribution of the species of larger use values in reason of the density and frequency. $\square \mathrm{RD}=$ relative density; $\mathrm{RF}=$ relative frequency; $\quad \mathrm{RI}=$ relative importance (use-value).

stipulacea, P. zehntneri, Ruprechtia sp. and Ziziphus joazeiro. According to Phillips \& Gentry (1993b) exist a general relation between ecological data (for example, density) and usefulness of a species: "One hypothesis is simply that because the most common taxa in the forest are those which are most frequently encountered, people had more opportunities to experiment and learn uses for these plants (...) Moreover, the more accessible a species is, the more likely that once culturally learnt such uses while persist. This is a variant of the ecological " apparency' hypothesis". This hypothesis could not be confirmed in this study. Besides, the reasonable number of species for the same function, confirms the idea of Mutchnick \& McCarthy (1997) second which few individuals of a species result that the people depend of many species for the same function. However, there are not enough evidences to reject the hypothesis totally. Thus, such results confirms that the characteristics affecting patterns of use may be different among communities and among tropical ecosystems.

The above-described uses for the dry forest by the rural community studied reflect a reasonable utilization of resources, evidencing that the preserved area is a source of medicinal and wood (carbon fuel and timber) resources. On one hand, it was found a low diversity of use categories named by the informants (Tab. 3), even with the unfolding of the categories here considered, contrasting with the number of uses 
reported for moist tropical forests (Balée 1987; Philips et al. 1994; Prance et al. 1987; De Walt 1999). On the other hand, the low number of use categories, recognized by the informants, implies also in a larger quantity of specialized taxa for a given use and in a smaller number of generalists taxa (species used for multiple purposes). The data strengthen the idea that medicinal plants are an important resource category, being similar with this respect to other reports (Rossato et al. 1999). Myracrodruon urundeuva and Schinopsis brasiliensis are very important species. They figure among the most important trees in the caatinga and are wide distributed along the seasonal dry forests of South America (Prado \& Gibbs 1993). Many species, if not the most, had low use-values, strengthening the idea that cultures in tropical forests make use of many species but only few of them are used intensively (Phillips et al. 1994). Would that lower diversity of use categories be related with the lowest floristic diversity of the dry forests?

Unfortunately, deforestation and conversion to agriculture of large areas of caatinga have been constant practices. Associated to this is the depletion of diversity in the region, due to destructive practices in land use and in the collection of natural resources. An example of these actions is the systematic cut down of woody species for local use and for obtainment of medicinal products. Though some species fitted within this exploitation category have a wide geographic distribution, the same are vulnerable because of systematic depletion (Pinto et al. 1986), as is the case of the above-mentioned $M$. urundeuva, $S$. brasiliensis and A. colubrina var. cebil, with a high demand (see also Almeida \& Albuquerque 2002).

There are strong utilitarian arguments in behalf of conservation of tropical forests (cf. Prance et al. 1987; Phillips et al. 1994; Voeks 1996; Phillips \& Gentry 1992a) and it has been already said that non-timber products may constitute an alternative to deforestation, including integration of natural forests management for timber products (cf. Salick et al. 1995). That may be even more important for dry forests. Management and use of resources can be compatible with preservation, generating ecological and social benefits, as some experiences already show (Hartshorn 1996). With respect to the caatinga, according the data obtained in this study, the disturbed areas can be integrated into management programs as an alternative source of nontimber products, enabling a lesser pressure on resources in natural areas. Disturbed areas and secondary forests are little considered in the different studies, and their potential has also been few considered especially with respect to their role in preserving biodiversity (Dotzauer 1998).

Finally, the data suggest that there are different patterns of use and knowledge of plant resources in tropical regions. The pharmacopoeia of the caatinga, for example, is characterized by species of the natural vegetation, though the disturbed area presents a relatively larger proportion of medicinal species. Preference for these medicinal resources is due to several factors, as: permanence of cultural values (historical factor - maintenance of the pattern) and adaptation to seasonality of this vegetation type (ecological factor - origin of the pattern). The flora in the natural areas is mostly deciduous and arboreal, with the herbaceous stratum ephemeral and seasonal, and the resources are available to the people along the whole year. Whereas the flora in the disturbed areas is predominantly herbaceous of short life cycle, present only during short periods of the year. There seems to be a pattern of resource use related to the characteristics of the different tropical forests, suggesting a kind of evolutive divergence on the use of those resources linked to historical or ecological factors, or even idiosyncrasies. However, efforts should be directed towards studies of other seasonal dry forests and of the knowledge of the relative importance of each one of the variables that determine the use of resources.

Thus, the caatinga should be of high conservation priority, because the most important species and families (with regard to their use) also are the ones that characterize the vegetation. Some species of those important families are vulnerable due to a systematic pursuit and, at least in the studied area, they are of low frequencies and densities. Research efforts should be directed to the sustainable management of those species integrated with vegetation management in disturbed areas, though those species are of minor local importance.

\section{Acknowledgements}

To the rural community at the municipality of Alagoinha, for their hospitality and receptivity during fieldwork and for the rich moments; to WWF and USAID, for their financial support; to CAPES (Coordenação de Aperfeiçoamento de Pessoal de Nivel Superior), for the fellowship granted to the first author; to biologists Fernando Valença, Cecília Almeida, Fernanda Melo, Kátia Chisaki and Mirtes Guedes, for their help during fieldwork. 


\section{References}

Alcoforado Filho, F.G.; Sampaio, E.V.S.B. \& Rodal, M.J.N. 2003. Florística e fitossociologia de um remanescente de vegetação caducifólia espinhosa arbórea em Caruaru, Pernambuco. Acta Botanica Brasilica 17(2): 287-303.

Albuquerque, U.P. \& Andrade, L.H.C. 2002a. Uso de recursos vegetais da caatinga: o caso do agreste do estado de Pernambuco (Nordeste do Brasil). Interciência 27: 336-346.

Albuquerque, U.P. \& Andrade, L.H.C. 2002b. Conhecimento botânico tradicional e conservação em uma área de caatinga no estado de Pernambuco. Acta Botanica Brasilica 16: 273-285.

Almeida, S.S., Silva, M.S. \& Rosa, N.A. 1995. Análise fitossociológica e uso de recursos vegetais na reserva extrativista do Cajarí, Amapá. Boletim do Museu Paraense Emílio Goeldi, série Botânica 11: 61-74.

Almeida, C.F.C.B.R. \& Albuquerque, U.P. 2002. Uso e conservação de plantas e animais medicinais no estado de Pernambuco (Nordeste do Brasil): um estudo de caso. Interciência 27: 276-285.

Araújo, E.L.; Sampaio, E.V.S.B. \& Rodal, M.J.B. 1995. Composição florística e fitossociologia de três áreas de Caatinga de Pernambuco. Revista Brasileira de Biologia 55: 595-607.

Balée, W. 1987. A etnobotânica quantitativa dos índios Tembé (Rio Gurupi, Pará). Boletim do Museu Paraense Emílio Goeldi, série Botânica 3: 29-50.

Caniago, I. \& Siebert, S.F. 1998. Medicinal plant ecology, knowledge and conservatiom in Kalimatan, Indonesia. Economic Botany 52: 229-250.

De Walt, S.J.; Bourfy, G.; Michel, L.R.C. \& Quenevo, C. 1999. Ethnobotany of the Tacana: quantitative inventories of two permanent plots of Northwestern Bolivia. Economic Botany 53: 237-260.

Dotzauer, H. 1998. The potential of secondary forest management from a development policy point of view. Plant Research and Development 47/48: 79-87.

Fidem. 2001. Fundação de Desenvolvimento Municipal. Perfil Municipal.

Frei, B.; Sticher, O. \& Heinrich, M. 2000. Zapotenc and Mixe use of tropical habitats for securing medicinal plants in México. Economic Botany 54: 73-81.

Griz, L.M.S. \& Machado, I.C. Fruiting phenology and seed dispersal syndromes in caatinga, a tropical dry forest in the northeast Brazil. Journal of Tropical Ecology 17: 303-321.

Hartshorn, G.S. 1996. Tropical forests: are conservation and forestry compatible? Selbyana 17: 1-5.
Martin, G. 1995. Ethnobotany. London, Chapman \& Hall.

Mutchnick, P.A. \& Mccarthy, B.C. 1997. An ethnobotanical analysis of the tree species common to the subtropical moist forests of the Petén, Guatemala. Economic Botany 51: $158-183$.

Nascimento, C.E.S.; Rodal, M.J.N. \& Cavalcanti, A.C. 2003. Phytosociology of remaining xerophytic woodland associated to an environmental gradient at the banks of São Francisco river - Petrolina, Pernambuco, Brazil. Revista Brasileira de Botânica 26(3): 271-287.

Phillips, O. \& Gentry, A.H. 1993a. The useful plants of Tambopata, Peru: I. Statistical hypothesis tests with a new quantitative technique. Economic Botany 47: 15-32.

Phillips, O. \& Gentry, A.H. 1993b. The useful plants of Tambopata, Peru: II. Additional hypothesis testing in quantitative ethnobotany. Economic Botany 47: 33-43.

Phillips, O.; Gentry, A.H.; Reynel, C.; Wilkin, P. \& GálvezDurand, C. 1994. Quantitative ethnobotany and amazonian conservation. Conservation Biology 8: 225-248.

Pinto, G.C.P.; Baptista, H.P. \& Ferreira, J.D.C.A. 1986. Espécies singulares no ecossistema das caatingas nordestinas. Pp. 469-476. In: Anais do XXXVII Congresso Nacional de Botânica. Sociedade Brasileira do Brasil/CNPq, Minas Gerais (Brasil).

Prado, D. \& Gibbs, P.E. 1993. Patterns of species distribution in the dry seasonal forests of South America. Annals of the Missouri Botanical Garden 80: 902-927.

Prance, G.T.; Balée, W.; Boom, B.M. \& Carneiro, R.L. 1987. Quantitative ethnobotany and the case for conservation in Amazonia. Conservation Biology 1: 296-310.

Rodal, M.J.N.; Sampaio, E.V.S.B. \& Figueiredo, M.A. 1992. Manual sobre métodos de estudo florístico e fitossociológico - ecossistema caatinga. Sociedade Botânica do Brasil, São Paulo.

Rossato, S.C.; Leitão Filho, H. \& Begossi, A. 1999. Ethnobotany of Caiçaras of the Atlantic Forest Coast (Brazil). Economic Botany 53: 387-395.

Salick, J.; Mejia, A. \& Anderson, T. 1995. Non-timber forest products integrated with natural forest management, Rio San Juan, Nicaragua. Ecological Applications 5: 878-895.

Sampaio, E.V.S.B. 1995. Overview of the Brazilian caatinga. Pp. 35-63. In: Seasonally dry tropical forests (S.H. Bullock, H.A. Mooney \& Medina). New York, Cambridge University Press.

Sharma, P.K. \& Sharma, J.D. 1997. The plant community of Comiphora wightii as an indigenous medicinal resource in a semi-arid ecosystem, in Pushkar (Rajasthan). Fitoterapia 68: 501-509.

Voeks, R.A. 1996. Tropical forest healers and habitat preference. Economic Botany 50: 381-400. 